\section{The hitherto undescribed male of Orthozona quadrilineata (Moore, 1882) (Lepidoptera: Erebidae)}

\section{Peter Smetacek ${ }^{1} \&$ I.J. Kitching ${ }^{2}$}

${ }^{1}$ Butterfly Research Centre, Jones Estate, Bhimtal, Uttarakhand 263136, India

${ }^{2}$ Department of Life Sciences, Natural History Museum, Cromwell Road, London SW7 5BD, U.K. Email: ${ }^{1}$ petersmetacek@rediffmail.com (corresponding author), i.kitching@nhm.ac.uk>

Madopa quadrilineata Moore, 1882 (Lepidoptera: Erebidae) was originally described from "Darjiling" (= Darjeeling, West Bengal, India) from an unstated number of specimens, which Moore (1882) stated were both in his own collection and that of Otto Staudinger. Both sexes were apparently represented among the syntypes, for Moore (1882) noted that the moth was "pale purplish-brownish-ochreous, brighter in female..."

Hampson (1895) later erected the genus Orthozona with $M$. quadrilineata as the only included species and the type species by original designation. However, he described only the female and diagnosed the genus on female characters: "Female: Palpi with the second joint porrect, of moderate length, and fringed with hair above, the third upturned and naked; a short sharp

Date of publication (online): 26 November 2012

Date of publication (print): 26 November 2012

ISSN 0974-7907 (online) | 0974-7893 (print)

Editor: George Mathew

Manuscript details:

Ms \# 02749

Received 05 April 2011

Final revised received 28 August 2012

Finally accepted 13 October 2012

Citation: Smetacek, P \& I.J. Kitching (2012). The hitherto undescribed male of Orthozona quadrilineata (Moore, 1882) (Lepidoptera: Erebidae) Journal of Threatened Taxa 4(14): 3366-3368.

Copyright: (c) Peter Smetacek \& I.J. Kitching 2012. Creative Commons Attribution 3.0 Unported License. JoTT allows unrestricted use of this article in any medium for non-profit purposes, reproduction and distribution by providing adequate credit to the authors and the source of publication.

Acknowledgements: PS is indebted to the Rufford Small Grant Foundation, U.K., for financial support during the period when this work was undertaken.

urn:Isid:zoobank.org:pub:FEE22F4B-2AC3-402E-BBE6-1DBF5BE5785E

\section{OPEN ACCESS | FREE DOWNLOAD}

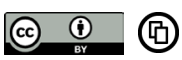

frontal tuft; antennae minutely ciliated; thorax and abdomen smoothly scaled, tibiae not hairy.

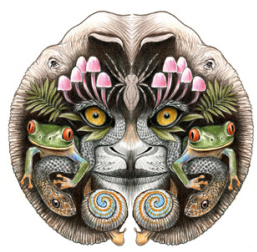
Forewing with the apex nearly rectangular; vein 3 [Cula] from before angle of cell. Hind wing with veins 4 [M3] and 5 [M2] from angle of cell; 3 [Cu1a] from before angle of cell."

We found only a single female syntype in the collection of the Natural History Museum, London (BMNH) (Images $1 \& 2$ ) thus it appears that Moore had only this female in his personal collection, which was subsequently passed on to the BMNH in 1894 . It may be that this is the sole specimen upon which Hampson based his diagnosis of the genus Orthozona. However, there may be male syntype(s) in Staudinger's collection (and which may now be in the Museum für Naturkunde, Leibnitz-Institut für Evolutions-und Biodiversitätsförschung an der Humboldt-Universität

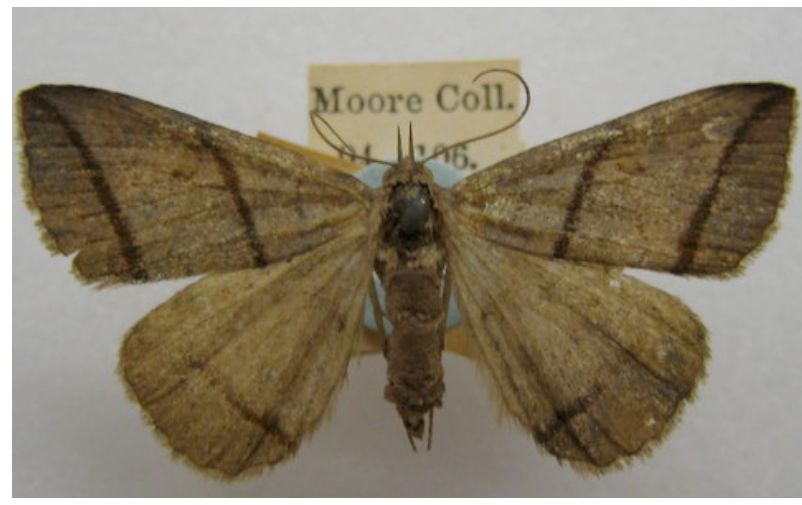

Image 1. Orthozona quadrilineata female syntype (BMNH).

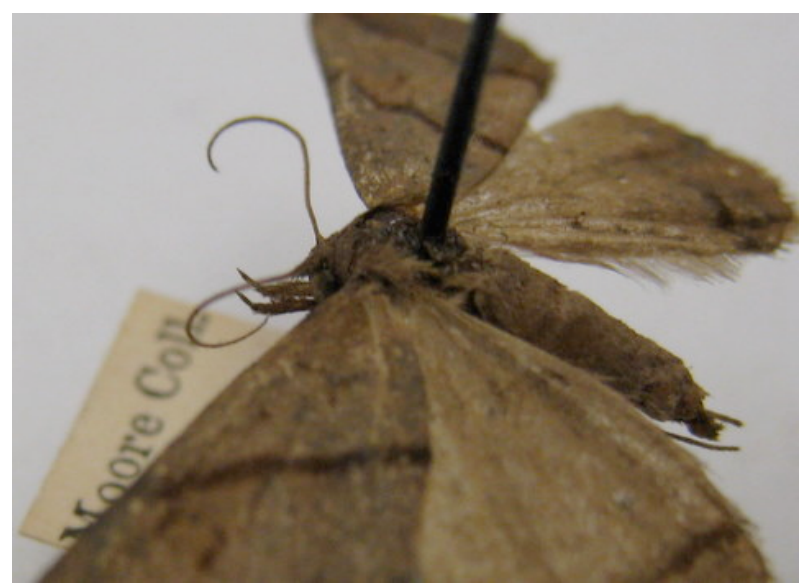

Image 2. Orthozona quadrilineata female syntype palpi (BMNH). 
zu Berlin, Germany) but we have not yet been able to confirm this. A label attached to the BMNH syntype states, "Agrees exactly with type in coll. Stdgr. [in Tams' handwriting] W.H.T. Tams det. [printed]". If Tams' statement that the agreement is exact is correct, then it would appear that the "type" in coll. Staudinger is also a female. It may therefore be that Moore missexed one of the syntypes. However, there may also be other, male (and as yet unrecognized) syntypes in coll. Staudinger, or perhaps Tams did not notice differences in palpus structure.

In the present paper, we illustrate and describe more fully the male of Orthozona quadrilineata (Images 3 \& 4), add male characters to the generic diagnosis of Orthozona and extend the range of the genus and species northwest to Gagar (2400m) in Nainital District of the Kumaon Himalaya, Uttarakhand, India.

\section{Material examined}

23.vii.2007, 1 male, Gagar, Nainital District, Uttarakhand, India, 2400m, 29024'47'N \& 79'32'39'E, leg. \& coll. P. Smetacek, Butterfly Research Centre, Jones Estate, Bhimtal, Uttarakhand, India; det. I.J. Kitching. Reference no.: PSTYPE 131; Forewing length: $17 \mathrm{~mm}$.

1 female (syntype): Darjeeling, 1864, Moore Coll, [18] 94-106 [BMNH accession number]. Forewing length: $15.5 \mathrm{~mm}$.

Male generic characters: Palpi recurved, third segment half the length of the second, antennae minutely ciliated; thorax and abdomen smoothly scaled; tibiae not hairy; forewing apex as in the female, nearly square; vein $\mathrm{Cula}$ from before angle of cell; hindwing M2 and M3 from angle of cell, vein Cu1a from before the angle.

Description of male: Head, thorax and abdomen fuscous brown. Forewing upperside pale reddish greybrown, with a rufous speck in the discal cell; a welldefined reniform stigma present, outlined in rufous; prominent oblique medial and submarginal rufous lines. Hindwing upperside pale fuscous, with an indistinct antemedial line and prominent submarginal rufous line from below costa to near anal angle. Forewing underside uniform grey with the costal area above cell pale cream. Hindwing underside grey, with dark antemedial and medial lines and crenulated pale postmedial band edged with fuscous.

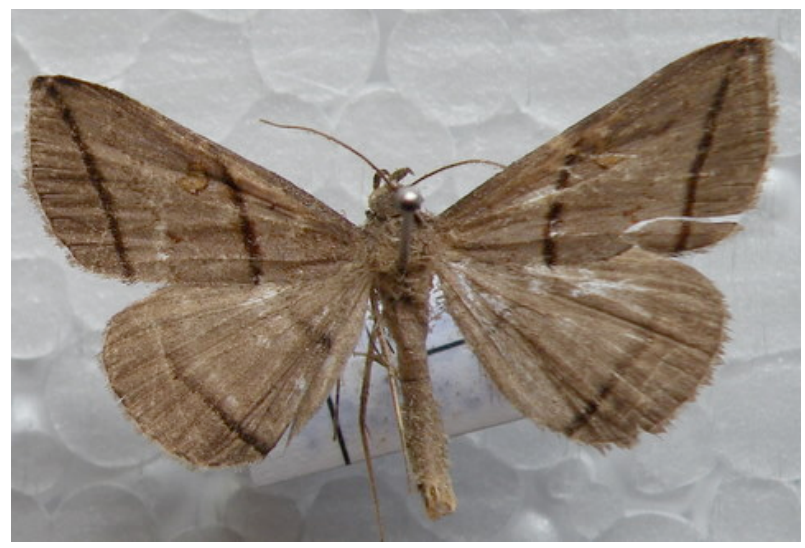

Image 3. Orthozona quadrilineata male (coll. P. Smetacek)

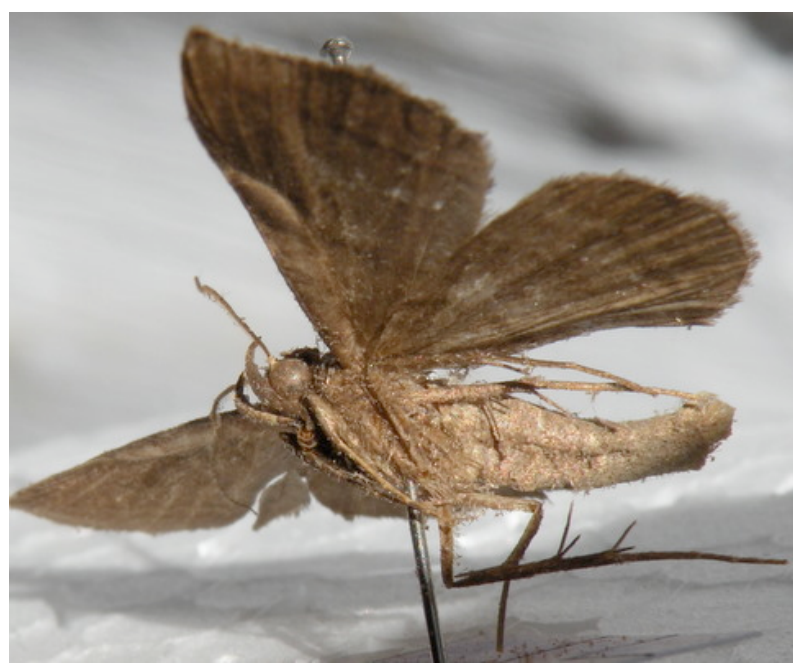

Image 4. Orthozona quadrilineata male palpi (coll. P. Smetacek).

\section{Discussion}

Currently, five species are recognized in Orthozona: O. quadrilineata, O. bilineata Wileman, 1915, O. curvilineata Wileman, 1915, O. karapina Strand, 1920 and O. rufilineata (Hampson, 1895) (Beccaloni et al. 2003). In the original description of Orthozona curvilineata from Taiwan, Wileman (1915) stated that "The palpi of the sexes differ in structure, but as regards this character the female agrees exactly with female $O$. quadrilineata, Moore, upon which the genus Orthozona, Hampson, was founded." A male syntype of $O$. curvilineata Wileman and its palpi are shown in Image 5 and a female in Image 6 , where the sexually dimorphic nature of these structures is clearly visible. A further male and the female syntype in the BMNH show the same dimorphism. However, as $O$. 


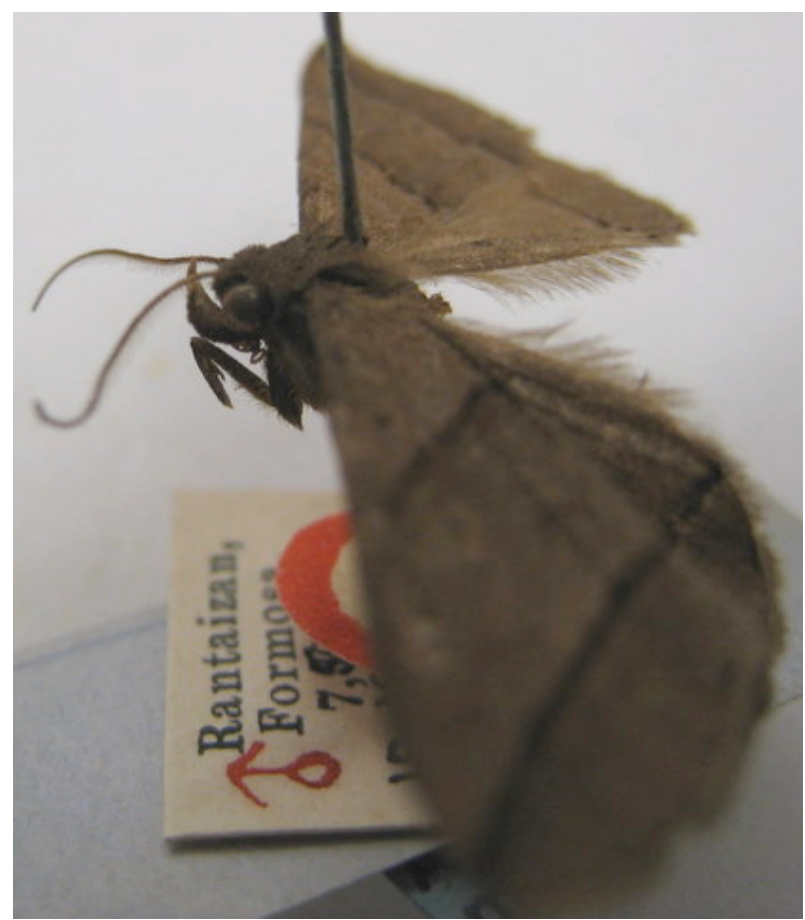

Image 5. Orthozona curvilineata male syntype showing palpi (BMNH).

quadrilineata is the type species and the condition of the palpi in the male was undescribed, there was an element of uncertainty whether sexual dimorphism in the structure of palpi was indeed a generic feature, rather than just a species-specific feature of $O$. curvilineata. After examining the present male specimen of $O$. quadrilineata, it appears more likely that sexual dimorphism in palpus structure is indeed a generic feature of Orthozona. Certainly, the male holotype of $O$. bilineata is consistent in having upturned palpi, but no female of this species is known. There are no specimens of $O$. karapina or O. rufilineata in the $\mathrm{BMNH}$, but a painting of the type of the latter appears to show a female (the abdomen is rather plump and has is rounded posteriorly) with porrect palpi, so this specimen is also consistent although examination of the specimen itself is required for confirmation.

Orthozona quadrilineata seems to be restricted to the higher parts of the subtropical evergreen forests of the Himalaya between Kumaon and Darjeeling. In the western Himalaya, this forest type consists mainly of

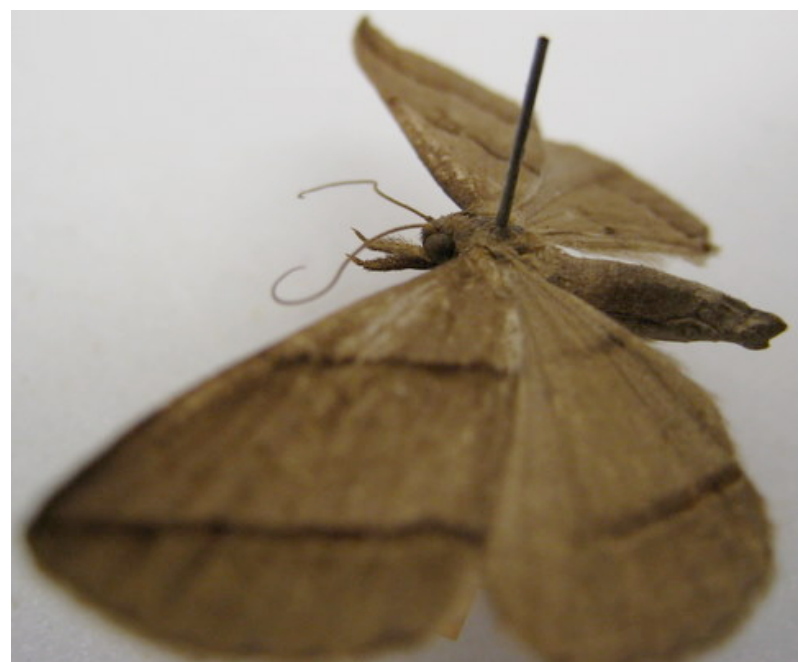

Image 6. Orthozona curvilineata female syntype showing palpi (BMNH).

Quercus leucotrichophora A Camus and Q. floribunda Lindley ex A. Camus (Fagaceae). The moth's range probably extends further east, through Bhutan and into Arunachal Pradesh, and possibly even further. However, it seems to be a rare species; in addition to the few (maybe only two) syntypes, only a single further specimen was captured at the mercury vapour lamp run at Gagar throughout 2007 and part of 2008.

\section{REFERENCES}

Beccaloni, G.W., M.J. Scoble, G.S. Robinson \& B. Pitkin (Editors) (2003). The Global Lepidoptera Names Index (LepIndex). World Wide Web electronic publication. http:// www.nhm.ac.uk/entomology/lepindex [accessed 31 March 2011]

Hampson, G.F. (1895). The Fauna of British India including Ceylon and Burma-Moths Vol. 3. Taylor \& Francis, London, 28+546pp.

Moore, F. (1882). Descriptions of Indian Lepidoptera Heterocera from the collection of the late Mr. W.S. Atkinson [Part 2]. pp. 89-198, in: Hewitson, W.C. \& F. Moore (1879-1888). Descriptions of New Indian Lepidopterous Insects from the Collection of the Late Mr. W.S. Atkinson. M.A., F.L.S., \&c. Asiatic Society of Bengal, Calcutta, 299pp+8pls.

Wileman, A.E. (1915). New species of Heterocera from Taiwan. The Entomologist 48: 39. 